\title{
A 60 kDa prolactin variant secreted by cervical cancer cells modulates apoptosis and cytokine production
}

\author{
ADRIÁN RAMÍREZ DE ARELLANO ${ }^{1,2}$, ANNIE RIERA LEAL ${ }^{1,2}$, EDGAR I. LOPEZ-PULIDO ${ }^{3}$, \\ LUIS RENEE GONZÁLEZ-LUCANO ${ }^{4}$, JOSÉ MACÍAS BARRAGAN ${ }^{6}$, SUSANA DEL TORO ARREOLA $^{2}$, \\ MARIEL GARCÍA-CHAGOLLAN ${ }^{5}$, CLAUDIA A. PALAFOX-SÁNCHEZ ${ }^{5}$, \\ JOSÉ F. MUÑOZ-VALLE ${ }^{5}$ and ANA LAURA PEREIRA-SUÁREZ ${ }^{2,5}$
}

\begin{abstract}
${ }^{1}$ Doctorate Program in Biomedical Sciences, University Center for Health Sciences, University of Guadalajara, Guadalajara, Jalisco; ${ }^{2}$ Department of Physiology, University Center for Health Sciences, University of Guadalajara, Guadalajara, Jalisco; ${ }^{3}$ Department of Clinics, University Center of Los Altos, Tepatitlan de Morelos, University of Guadalajara, Guadalajara, Jalisco; ${ }^{4}$ Institute of Technology and Higher Education of Monterrey, Campus Guadalajara, Zapopan, Jalisco; ${ }^{5}$ Research Institute in Biomedical Sciences, University Center for Health Sciences, University of Guadalajara, Guadalajara, Jalisco; ${ }^{6}$ Department of Health Sciences, University Center of Los Valles, University of Guadalajara, Ameca, Jalisco, Mexico
\end{abstract}

Received August 25, 2017; Accepted January 10, 2018

DOI: $10.3892 /$ or.2018.6222

\begin{abstract}
Prolactin (PRL) is associated with different types of cancer, such as cervical cancer. Recombinant PRL has antiapoptotic effect on cervical cancer cells, and it can also induce cytokine production on macrophages. A $60 \mathrm{kDa}$ variant of PRL is produced by cervical cancer cells. The aim of the present study was to evaluate this variant's bioactivity, to test its effect on cervical cancer cell apoptosis, and to assess its ability to induce cytokine production on THP-1 macrophages. First, $60 \mathrm{kDa}$ PRL was isolated and used to stimulate Nb2 cells. Later, apoptosis was measured after exposure to $60 \mathrm{kDa}$ PRL. Finally, cytokines were measured on THP-1 stimulated supernatants. Our results show that $60 \mathrm{kDa}$ PRL increased Nb2 cell proliferation. Apoptosis was decreased after stimuli with $60 \mathrm{kDa}$ PRL in cervical cancer cells. IL- $1 \beta$ and TNF- $\alpha$ are produced by THP-1 macrophages after stimuli. These results suggest that $60 \mathrm{kDa}$ PRL produced by cervical cancer cells is able to reduce apoptosis in $\mathrm{HeLa}, \mathrm{SiHa}$ and $\mathrm{C}-33 \mathrm{~A}$ cells and induce IL-1 $\beta$ and TNF- $\alpha$ production by THP-1 macrophages.
\end{abstract}

\section{Introduction}

Prolactin (PRL) is a peptidic hormone that has been shown to play multiple biological functions. In addition to its clear

Correspondence to: Dr Ana Laura Pereira-Suárez, Department of Physiology, University Center for Health Sciences, University of Guadalajara, CP 44340, Guadalajara, Jalisco, México

E-mail: analauraps@hotmail.com

Key words: prolactin, cervical cancer, bioactivity, apoptosis role in lactation, PRL participates in some cellular processes such as proliferation, growth and differentiation (1). PRL can modulate the immune system, being involved in alterations of both cellular and humoral responses $(2,3)$. For instance, PRL is able to influence different immunological processes such as proliferation (4), antigen presentation (5) and immunoglobulin production (6).

Human PRL, besides being expressed in the pituitary gland, is independently and differentially expressed by different tissues such as breast, prostate, endometrium and immune cells (7).

Several studies have described the modulating effects of PRL involving disturbances in chronic inflammatory processes such as autoimmune diseases (8). Low doses of PRL are able to induce the production of proinflammatory cytokines such as TNF- $\alpha$, IL- $1 \beta$, IFN- $\gamma$ in murine peritoneal macrophages; however, higher doses of PRL $(1,000 \mathrm{ng} / \mathrm{ml})$ induced IL-10 synthesis with significant inhibition of proinflammatory cytokine production in the same cells $(9,10)$. One study showed that proinflammatory cytokines induced in vitro PRLR expression in pulmonary fibroblasts (11).

Increased PRL levels have been shown in autoimmune diseases, such as systemic lupus erythematosus (SLE), rheumatoid arthritis (RA), systemic sclerosis and Sjögrensindrome (12-14). Proinflammatory cytokines have the ability to induce pituitary PRL secretion (15), which in turn may contribute to circulating pool of the hormone. Several studies have focused on the blockade of proinflammatory cytokines to prevent autoimmune diseases in murine models (16-18), which may be a possible therapeutic strategy.

The PRL protein can undergo post-translational modifications that include glycosylation, phosphorylation, polymerization and proteolytic cleavage, which can influence its biological activities (19). Pituitary PRL is a $23 \mathrm{kDa}$ polypeptidic hormone; however, other forms of PRL called 
macroprolactin (over $100 \mathrm{kDa}$ ) and big PRL (40-60 kDa) have been identified in human serum $(19,20)$. The $60 \mathrm{kDa}$ PRL corresponds to the big PRL form, which is a dimer that may be an aggregate of glycosylated subunits $(25 \mathrm{kDa})(21)$, and this modification may be involved in mechanisms of biosynthesis, secretion, and clearance of the hormone (19).

There is also evidence of the association between PRL/PRLR and tumorigenesis in clinical samples. A previous study of our research group showed the relation of high PRLR expression and malignant laryngeal tumors (22).

In a previous study we provided evidence that the cell lines and tissues of cervical cancer synthesize a $60 \mathrm{kDa}$ PRL variant unlike the non-tumorigenic keratinocytes (HaCaT) $(23,24)$. This PRL variant has been previously identified in peripheral blood mononuclear cells (PBMC) from patients with SLE and THP-1 monocytes $(24,25)$.

The diverse activities of PRL are mediated by PRLR, and this complex may activate several signaling pathways including Jak-STAT $(26,27)$, MAPK (28) and PI3K (29,30). However, in a previous study, our group reported that STAT3 is an important transcription factor for recombinant hPRL (rec-hPRL) to carry its effects (31).

There is an association between PRL and its receptor's overexpression with the development of different types of cancer such as breast, laryngeal, prostate, colon and cervical cancer $(22,23,32-36)$. The role of circulating PRL in tumorigenesis, mainly in breast cancer, has been a topic of debate for more than 20 years since various epidemiological studies were unable to reach unified conclusions on the correlation between circulating PRL levels and risk for cancer $(37,38)$. However, there is no evidence that this $60 \mathrm{kDa}$ PRL, which may be acting in an autocrine manner, may cooperate with the development of cancer.

Cervical cancer is still a major public health problem and the third most common type of cancer in women worldwide (39). Persistent high-risk human papillomavirus infection is the main risk factor for cervical cancer; however, there are other important cofactors for this outcome. Previous results of our group show that a long PRLR isoform is mainly expressed in cervical cancer tissues (40), and its overexpression is associated to cell survival by inhibition of apoptosis (23). Moreover, we found the presence of a $60 \mathrm{kDa}$ PRL isoform that is present in cervical cancer cells (23).

There are no studies that evaluate the biological effect of PRL produced by tumor cells and the different responses due to the existence of different isoforms. The aim of the present study was to obtain the $60 \mathrm{kDa}$ PRL produced by cervical cancer cells and to evaluate some aspects of its functionality. We tested whether the $60 \mathrm{kDa}$ PRL is bioactive in Nb2 cells and its effect on apoptosis in cervical cancer cells. In addition, we assessed its impact on the induction of proinflammatory cytokines in THP-1 macrophages.

\section{Materials and methods}

Reagents. Rec-hPRL (L-4021) and 3-(4,5-dimetylthiazol2-yl)-2,5-diphenyltetrazolium reagent (MTT) were obtained from Sigma-Aldrich ${ }^{\circledR}$ (St. Louis, MO, USA). Polyvinylidene difluoride (PVDF) membranes, enhanced chemiluminescence (ECL), and western blotting detection kit (WBKLS0500) were purchased from Merck Millipore (EMD Millipore Corporation Billerica, MA, USA) as well as Amicon ${ }^{\circledR}$ Ultra $0.5 \mathrm{ml}$ centrifugal filters. Monoclonal antibody anti-PRL (E-9) sc-48383 was obtained from Santa Cruz Biotechnology, Inc. (Santa Cruz, CA, USA). Dulbecco's modified Eagle's medium (DMEM), DMEM advanced, charcoal stripped fetal bovine serum (FBS) and antibiotic/antimicotic were purchased from Gibco Life Technologies (Carlsbad, CA, USA). Polyclonal antibodies anti-pSTAT3 (Ser 727), sc-13564, anti-bcl-xl (H-5) sc-8392 and anti-bcl-2 (C-2) sc-7382 were obtained from Santa Cruz Biotechnology. Polyclonal antibody anti-survivin AF886 was purchased from R\&D Systems (R\&D Systems, Inc., Minneapolis, MN, USA). Inhibitor for JAK/STAT signaling pathway $\alpha$-cyano-(3,4-dihydroxy)-Nbenzylcinnamide (AG490) was dissolved in dimethyl sulfoxide (DMSO) and stored at $-20^{\circ} \mathrm{C}$ as recommended by the manufacturer. Phorbol 12.myristate 13-acetate (PMA) was obtained by Sigma (P8139). $\mu$ MACS $^{\text {тM }}$ Protein G MicroBeadsMultiMACS ${ }^{\mathrm{TM}}$ Protein $\mathrm{G}$ kit was provided by MiltenyiBiotec. Finally, multiple cytokine magnetic bead MIHCYTOMAG-60K-05 kit was manufactured by MILLIPLEX $^{\circledR}$ MAP.

Cell culture. Cervical cancer derived cells (HeLa, SiHa and C-33A), non-tumorigenic immortalized keratinocytes (HaCaT), as a negative control, THP-1 monocitic cell line, and $\mathrm{Nb} 2$ rat lymphoma-derived cells were used for stimulation with PRL assays. All the cell lines were obtained from American Type Culture Collection (ATCC; University Boulevard Manassas, VA, USA) and were grown with DMEM, DMEM advanced or RPMI-1640 medium supplemented with $5 \%$ of charcoal stripped FBS, penicillin G, streptomycin and amphotericin B.

PMA was used to differentiate THP-1 monocytes into macrophages, and its concentration was $200 \mathrm{nM}$ for $72 \mathrm{~h}$.

Cells were cultured in a jacket-water incubator at $37^{\circ} \mathrm{C}$ with an atmosphere of $5 \% \mathrm{CO}_{2}$. The cells were grown to reach $80 \%$ confluence, thus they could be used for assays.

Western blotting. Protein $(40 \mu \mathrm{g})$ from supernatants of cervical cancer cells were mixed with loading buffer and denatured at $95^{\circ} \mathrm{C}$ for $5 \mathrm{~min}$. Afterwards, they were loaded on $10 \%$ SDS polyacrylamide gels to be resolved. Protein transference was carried out in PVDF membranes (Bio-Rad Laboratories, Hercules, CA, USA). Blocking solution was prepared with $5 \%$ of Blotting Grade Blocker (Bio-Rad Laboratories), and membranes were incubated in this solution for $2 \mathrm{~h}$. Solutions with primary antibodies were prepared at a dilution of 1:500, and membranes were kept overnight followed by the secondary antibody solutions (diluted 1:5,000). The process was developed with a chemiluminescence system (Immobilion, Merck Millipore). MicroChemi 6.0 was also used to reveal membranes and measure optical density.

Immunoprecipitation with magnetic beads. Immunoprecipitation was carried out to isolate the $60 \mathrm{kDa}$ isoform of PRL. Supernatants of different cervical cancer cell cultures were tested by western blotting to evaluate whether the isoform was present. Positive samples $(250 \mu \mathrm{l})$ were mixed with 
$10 \mu \mathrm{l}$ of anti-PRL and $50 \mu \mathrm{l}$ of microbeads using $\mu \mathrm{MACS}^{\mathrm{TM}}$ Protein G MicroBeadsMultiMACS ${ }^{\mathrm{TM}}$ Protein G kit. The mixture was kept on ice for $30 \mathrm{~min}$, and then it was transferred into magnetic columns followed by four rinse steps and a final one to detach the protein with an acid glycine solution. After testing the correct PRL isolation, the protein was quantified to proceed with stimuli.

Molecular weight cut-off filtration. The PRL isolated from cervical cancer cell supernatants was filtered to purify the $60 \mathrm{kDa}$ isoform using Amicon ${ }^{\circledR}$ Ultra $0.5 \mathrm{ml}$ centrifugal filters setting up a molecular weight cut-off at $50 \mathrm{kDa}$. Filtration conditions were $14,000 \times \mathrm{g}$ for $30 \mathrm{~min}$ for concentration spin and $1,000 \mathrm{x} \mathrm{g}$ for $2 \mathrm{~min}$ for reverse spin.

Quantification of $60 \mathrm{kDa} P R L$. Lowry method was used to measure the isolated and purified $60 \mathrm{kDa} P R L$, having a bovine serum albumin standard curve and reading samples by triplicate. The plates were read in an iMark microplate reader Bio-Rad version 6.1.

Silver nitrate staining. Polyacrylamide gels (10\%) were used to determine the presence of PRL after isolation assays and to determine the correct $60 \mathrm{kDa}$ isoform isolation after molecular weight cut-off filtration. After electrophoretic running, a silver nitrate staining was performed.

Nb2 cell proliferation assay. Nb2 cells were cultured with complete medium (10\% of horse serum and $10 \%$ of FBS) and $24 \mathrm{~h}$ before the assay cells were transferred to maintenance medium (1\% FBS). Finally, assay medium (0.1\% FBS) was used to carry out the test. Cells were grown for $60 \mathrm{~h}$ with no stimulus, rec-hPRL (200 ng/ml), or $60 \mathrm{kDa}$ PRL (200 ng/ml). MTT $(5 \mathrm{mg} / \mathrm{ml})$ was added at a proportion of one tenth of final medium volume and incubated for $4 \mathrm{~h}$, according to the protocol of the manufacturer. Blue formazan crystals were solubilized with acidified isopropanol, and absorbances were read at a wavelength of $570 \mathrm{~nm}$ in an Epoch Microplate Spectrophotometer (BioTek Instruments, Inc., Winooski, VT, USA).

Apoptotic assay (TUNEL assay). The kit APO-BrdU (Invitrogen, Carlsbad, CA, USA) was used to carry out TUNEL assay. Cells were grown in 8-well chamber slides seeded with $5 \times 10^{4}$ cells/well, and treated with etoposide alone or in combination with the $60 \mathrm{kDa}$ PRL for $24 \mathrm{~h}$ and incubated at $37^{\circ} \mathrm{C}$. The slides were washed with PBS and fixed with $4 \%$ paraformaldehyde for $30 \mathrm{~min}$ at room temperature. Fixed cells were washed and permeabilized using $0.2 \%$ Tween-20 for $10 \mathrm{~min}$ and then incubated with terminal deoxynucleotidyl transferase and BrdU for $1 \mathrm{~h}$ at $37^{\circ} \mathrm{C}$. After rinsing with PBS, cells were treated with Alexa Fluor 488 dye-labeled antiBrdU antibody at $37^{\circ} \mathrm{C}$ for 30 min and mounted with a glass coverslip. Staining of DNA fragmentation was observed with ultraviolet fluorescent microscope (Carl Zeiss, Jena, Germany) counting at least 200 cells/well. Semi-automatic quantification was performed using the cell counter function of Image-pro Plus 6.0 software. The color intensity of the positive objects (green) was manually preset for each pattern (pixel/pixel) based on the hue-saturation-intensity (HSI) histogram. The final option of the 'count/size' command allows to obtain the mean optical densities of 5 fields/sample.

Human cytokine magnetic bead panel assay. Cytokines secreted by THP-1 cells differentiated into macrophages were quantified using a multiple cytokine magnetic bead kit (MILLIPLEX ${ }^{\circledR}$ MAP, MIHCYTOMAG-60K-05; Millipore) following the instructions of the manufacturer. This kit was targeted to TNF- $\alpha$, IL-1 $\beta$, IL-6, IL-12 and IL-10.

Statistical analysis. Data were analyzed using (GraphPad Prism software (GraphPad version 6.01). Significant effects were determined using ANOVA. Statistically significant differences were considered for P-values $<0.05$.

\section{Results}

Isolation and purification of $60 \mathrm{kDa} P R L$. After demonstrating the presence of 60 and $80 \mathrm{kDa}$ isoforms of PRL in total protein extracts from cervical cancer cell lines HeLa, SiHa and C-33A (23), it was decided to evaluate whether both isoforms were also present in these cell culture supernatants. The $60 \mathrm{kDa}$ variant of PRL was present in all of the 18 samples of cervical cancer cell supernatants evaluated; in contrast, the $80 \mathrm{kDa}$ variant was absent (Fig. 1A). Additionally, the supernatants of non-tumorigenic immortalized keratinocytes (HaCaT) were also evaluated and the $60 \mathrm{kDa}$ variant was not found (data not shown). Hence, compared with cervical cancer cell lines, HaCaT does not produce the $60 \mathrm{kDa}$ PRL variant, and do not express long isoforms of PRLR (23).

Due to its absence in HaCaT cell line, the PRL isoform of $60 \mathrm{kDa}$ was isolated only from cervical cancer cells (particularly from HeLa) and was collected using magnetic bead immunoprecipitation assays. After a second elution, PRL was not recovered, which means that one rinse was enough to recover the total immunoprecipitated PRL (Fig. 1B).

To identify the optimal conditions for the best purification performance, different volumes of the supernatants $(250,500$ and $1,000 \mu \mathrm{l})$ and the antibody ( 1 and $2 \mu \mathrm{g}$ ) were assayed. The highest amount of protein obtained was accomplished with $250 \mu \mathrm{l}$ of supernatant (Fig. 1B) and $2 \mu \mathrm{g}$ of antibody (Fig. 1C).

During the immunoprecipitation assays, positive and negative controls were used to test the correct PRL isolation. In Fig. 1D it is observed that when using PBS buffer (negative control) there are no bands present, which means no protein was recovered. In contrast, when using rec-hPRL (positive control), we observed a band that shows immunoprecipitation is carried out correctly.

To confirm the correct isolation of PRL and exclude the presence of other interfering proteins, a silver staining assay in polyacrylamide gels was performed, and we detected the presence of PRL isoform of $60 \mathrm{kDa}$ and other lower molecular weight bands, which may be degraded proteins (Fig. 1E). These fragments were eliminated by molecular weight cut-off filtration and the unique presence of the $60 \mathrm{kDa}$ band was observed by a silver staining assay in polyacrylamide gels (Fig. 1F).

Bioactivity of $60 \mathrm{kDa} P R L$. Nb2 cell proliferation assay was used to determine whether the autocrine $60 \mathrm{kDa}$ PRL is 

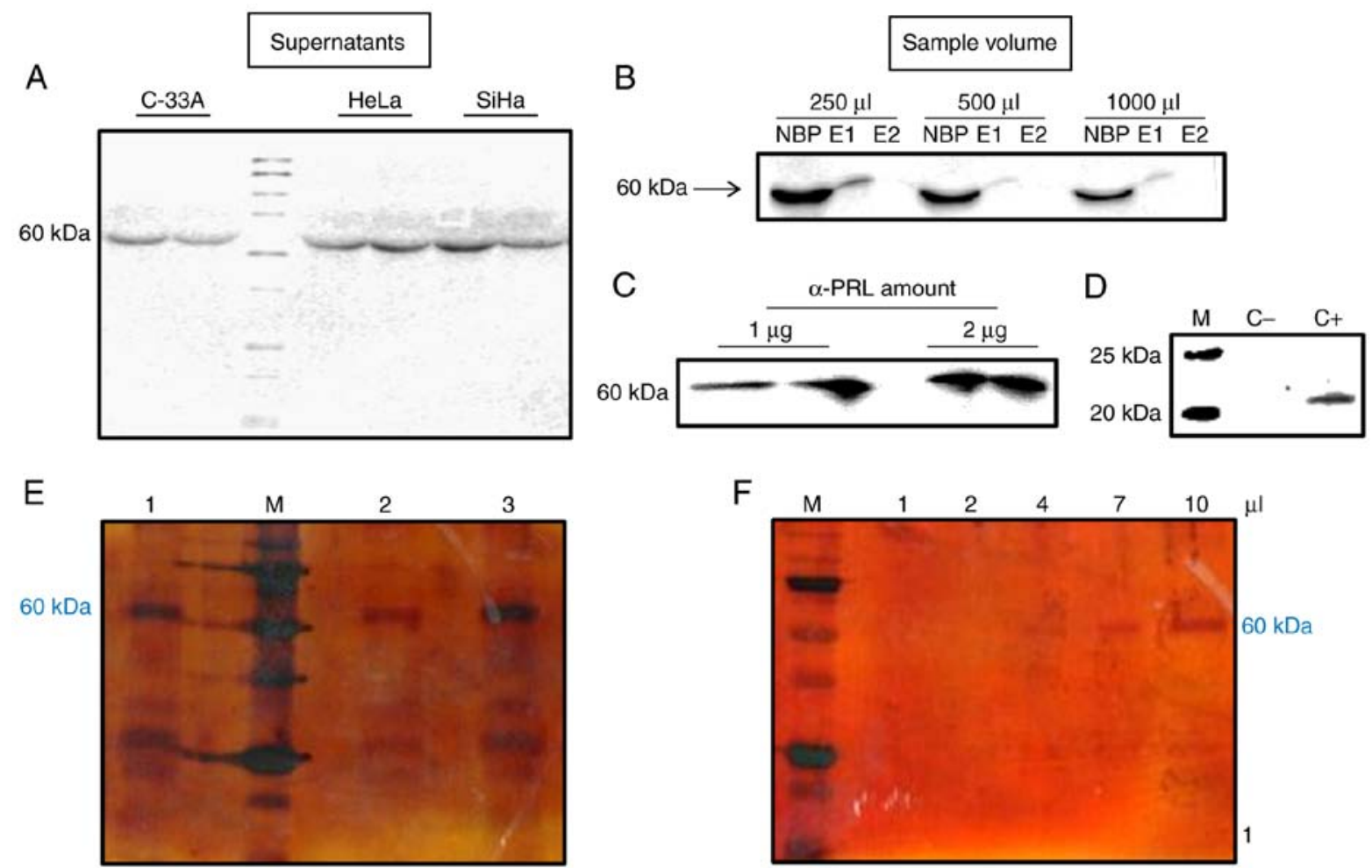

Figure 1. Isolation of $60 \mathrm{kDa}$ PRL from cervical cancer cell supernatants. (A) Presence of $60 \mathrm{kDa}$ PRL on supernatants of HeLa, SiHa and C-33A by western blotting. (B and C) To standarize optimal conditions for immunoprecipitation of $60 \mathrm{kDa}$ PRL different volumes of sample [250, 500 and 1,000 $\mu 1$ (B) and amounts of $\alpha$-PRL antibody (1 and $2 \mu \mathrm{g}$ ) (C) were tested by western blotting (NBP, non-bound protein; E1, elution 1; E2, elution 2)]. (D) Polyacrylamide gel stained with silver nitrate showing the presence of $60 \mathrm{kDa}$ PRL after immunoprecipitation $(1,2$ and 3 , are 3 different samples of HeLa supernatants, $\mathrm{M}$, molecular weight marker). (E) Presence of a unique $60 \mathrm{kDa}$ PRL band on a polyacrylamide gel with different volumes after ultrafiltration of immunoprecipitated supernatants.

bioactive. $\mathrm{Nb} 2$ cell proliferation assay is the gold standard to evaluate PRL bioactivity, based on the studies carried out by Noble et al. In these studies, they used a broad panel of hormone stimuli and identified that the only ones that induced proliferation on the $\mathrm{Nb} 2$ cell line were the members of the PRL family, particularly PRL, whose effects were observed to be in a more sensitive manner (even to $1 \mathrm{ng} / \mathrm{ml}$ ). This is the reason why we decided to use this model to evaluate $60 \mathrm{kDa}$ PRL bioactivity $(41,42)$.

$\mathrm{Nb} 2$ cells were stimulated either with rec-hPRL or $60 \mathrm{kDa}$ PRL (200 ng/ml for $60 \mathrm{~h}$ ), and then compared to non-stimulated cells. The concentration of hormones and time of stimulus had been standardized in previous studies published by our group (24).

As observed in Fig. 2, $60 \mathrm{kDa}$ PRL strongly induced proliferation in $\mathrm{Nb} 2$ cells almost in a 2-fold basis and this behavior is similar to that observed with rec-hPRL.

Antiapoptotic effect of $60 \mathrm{kDa} P R L$ in cervical cancer cells. Our research group previously showed that rec-hPRL has an important effect on cervical cancer cell survival by inhibition of apoptosis (23) and the optimal concentration of rec-hPRL and etoposide was tested in previous studies for apoptosis assays $(23,31)$. This is the reason to evaluate whether the $60 \mathrm{kDa}$ PRL has the same capacity. The effect of the $60 \mathrm{kDa}$ PRL on a model of apoptosis induced by etoposide in cervical cancer cells was analyzed. Treatment with etoposide (30 $\mu \mathrm{g} / \mathrm{ml})$ augmented the number of cells with fragmented

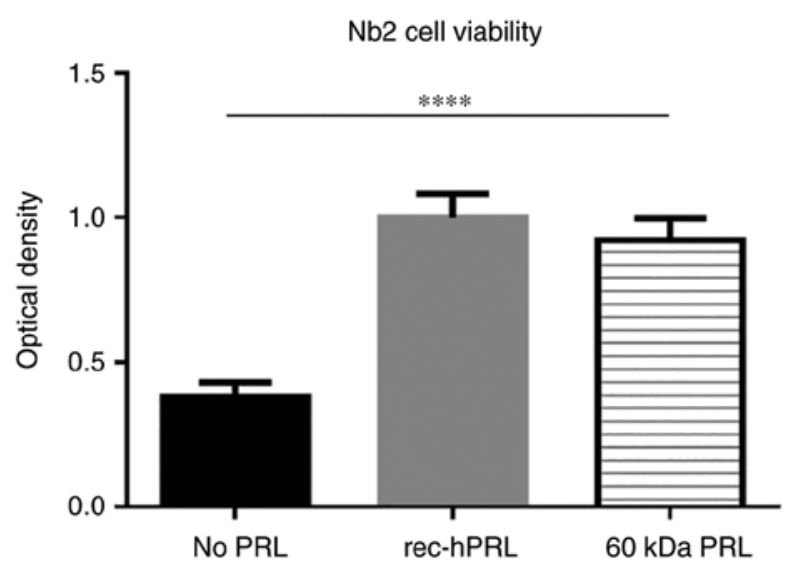

Figure 2. Bioactivity of $60 \mathrm{kDa}$ PRL on Nb2 cells. Nb2 cells were stimulated with recombinant human PRL (rec-hPRL) and $60 \mathrm{kDa}$ PRL for $60 \mathrm{~h}$ and compared with cells without stimulus, cell viability was measured by MTT $\left({ }^{* * * *} \mathrm{P}<0.0001\right)$.

DNA in all cell lines after $24 \mathrm{~h}$ of incubation, as expected. $60 \mathrm{kDa}$ PRL (200 ng/ml) costimulus significantly decreased the number of cells with DNA fragmentation. As observed in optical analysis, HeLa, SiHa and C33A reduced its apoptotic cells when they were stimulated with $60 \mathrm{kDa}$ PRL (from 698 to 248.6 for $\mathrm{HeLa}$, from 642 to 302.4 for $\mathrm{SiHa}$, and from 695 to 407.6 for C33A; Fig. 3A). Representative images of immunofluorescence from TUNEL assays in HeLa cell line are shown (Fig. 3B). 
A

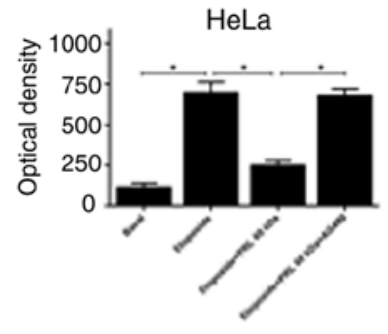

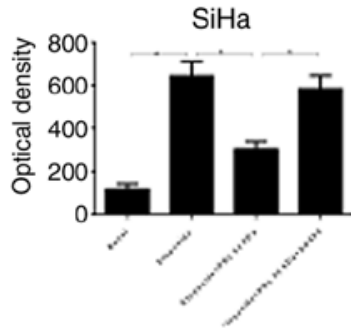

Eto

Eto+PRL

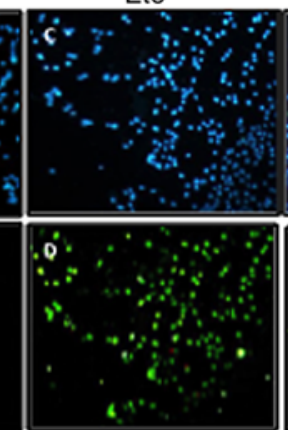

D

\section{C}

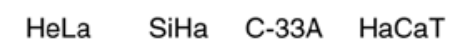

$\begin{array}{llllllll}0 & 30 & 0 & 30 & 0 & 30 & 0 & 30 \mathrm{~min}\end{array}$

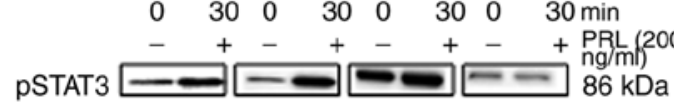

$\beta$-actin

$-\infty-\cdots$ $43 \mathrm{kDa}$
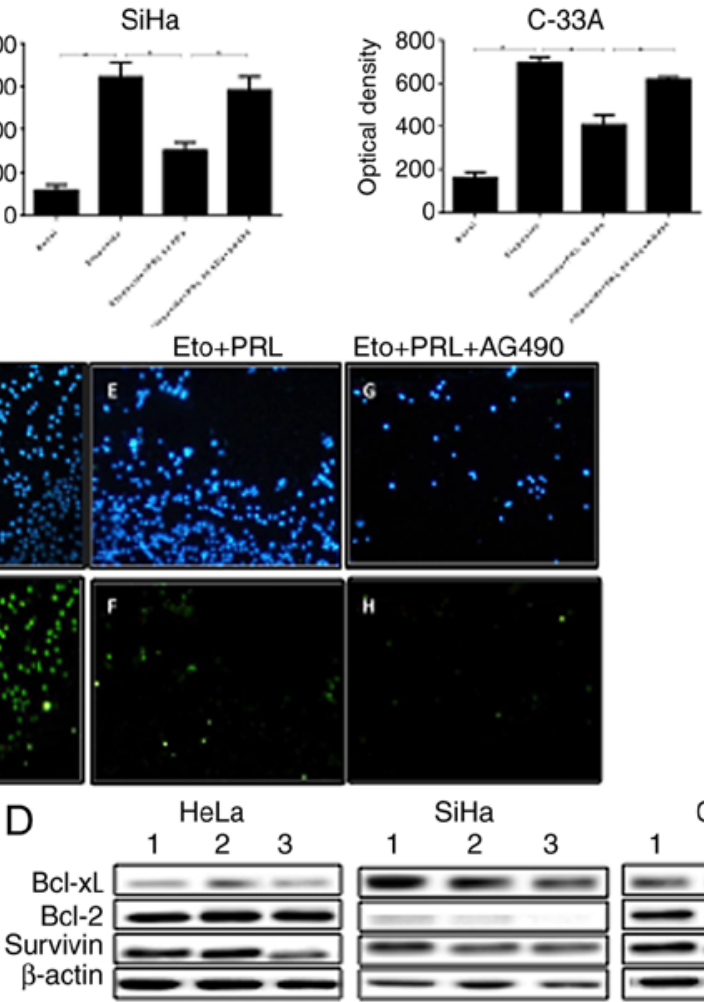

Eto+PRL+AG490

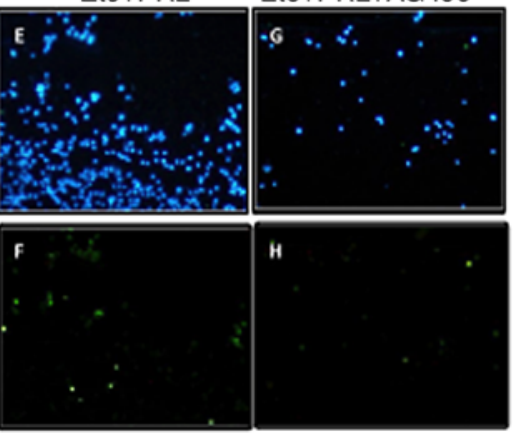

$\mathrm{SiHa}$
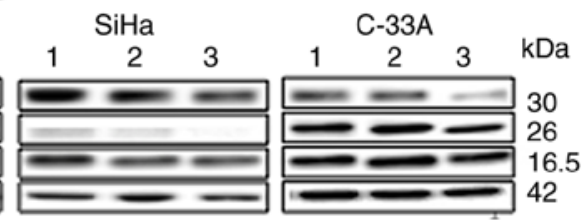

Figure 3. Effect of $60 \mathrm{kDa}$ PRL on apoptosis induced by etoposide in cervical cancer cells. (A) HeLa, SiHa and C-33A were stimulated with $60 \mathrm{kDa}$ PRL for $24 \mathrm{~h}$. Apoptosis was measured by TUNEL assays and optical analysis was performed with the software Image-pro $\left.\mathrm{Plus} 6.0{ }^{* * * * *} \mathrm{P}<0.0001,{ }^{* *} \mathrm{P}<0.01,{ }^{*} \mathrm{P}<0.05\right)$. (B) Representative images of immunostainning from TUNEL assays in HeLa cells, apoptotic cells (green B, D, F, H) and DAPI staining (blue A, C, E, G) are shown. (C) Phosphorylation of STAT3 is shown after 30 min of stimulus with $60 \mathrm{kDa}$ PRL in HeLa, SiHa and C33A. (D) Expression of antiapoptotic proteins after stimuli with 60 kDa PRL for 48 alone or in combination with AG490 in HeLa, SiHa and C-33A cells. 1, not stimulus; 2, with 60 kDa PRL; 3, with 60 kDa PRL plus AG490.

Since rec-hPRL is able to induce phosphorylation of STAT3, and this pathway is required for antiapoptotic effects of PRL in cervical cancer cells (31), we decided to evaluate whether autocrine $60 \mathrm{kDa}$ PRL has the same capacity. The $60 \mathrm{kDa}$ PRL augmented STAT3 phosphorylation in HeLa, SiHa and C33A; however, in HaCaT cells was not observed (Fig. 3C).

The antiapoptotic effect the autocrine $60 \mathrm{kDa}$ PRL exerted was abolished when Jak-STAT signaling pathway was inhibited with AG490 inhibitor (Fig. 3A and B). This behavior was similar on the three cervical cancer cell lines used and similar to that observed in previous studies of our group analyzing apoptosis of cervical cancer cells and STAT3 activation in response to rec-hPRL (31).

Since a similar behavior was observed regarding the bioactivity and the antiapoptotic effect exerted by $60 \mathrm{kDa}$ PRL compared to rPRL in cervical cancer cells, we decided to evaluate how the expression of antiapoptotic proteins was modulated.

In HeLa and C-33A cells, the expression of Bcl-xL and Survivin slightly increased after stimuli with $60 \mathrm{kDa}$ PRL; as expected protein levels decreased when STAT3 pathway is blocked. For Bcl-2 these changes were not observed. However, in $\mathrm{SiHa}$ the expression of these antiapoptotic proteins were not modified (Fig. 3D).

The $60 \mathrm{kDa}$ PRL induces TNF- $\alpha$ and $I L-1 \beta$ production in THP-1 macrophages. The THP-1 monocytes were differentiated into macrophages. After $48 \mathrm{~h}$ of stimulation with

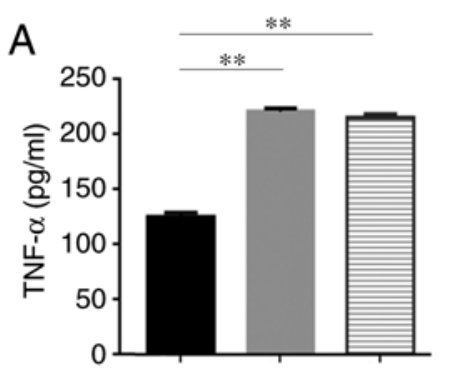

No stimulus $60 \mathrm{kDa}$ PRL $(200 \mathrm{ng} / \mathrm{ml})$ 口60 kDa PRL $(300 \mathrm{ng} / \mathrm{ml})$

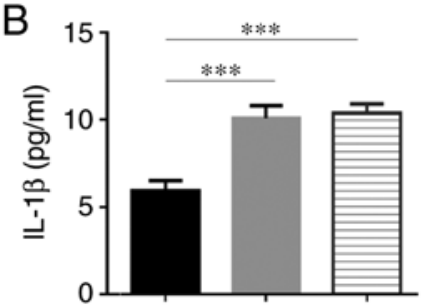

no stimulus $60 \mathrm{kDa}$ PRL $(200 \mathrm{ng} / \mathrm{ml})$ $\square 60 \mathrm{kDa}$ PRL $(300 \mathrm{ng} / \mathrm{ml})$

Figure 4. Proinflammatory cytokine production by THP-1 macrophages in response to $60 \mathrm{kDa}$ PRL. (A) TNF $\alpha$ and (B) IL- $1 \beta$ production by THP-1 macrophages stimulated with 200 and $300 \mathrm{ng} / \mathrm{ml}$ of $60 \mathrm{kDa}$ PRL for $48 \mathrm{~h}$ was measured using MILLIPLEX ${ }^{\circledR}$ MAP, MIHCYTOMAG-60K-05 kit $\left({ }^{* *} \mathrm{P}<0.01,{ }^{* * *} \mathrm{P}<0.001\right)$.

the $60 \mathrm{kDa}$ PRL (200 and $300 \mathrm{ng} / \mathrm{ml}$ ), the concentration of cytokines on macrophage supernatants was measured by MILLIPLEX $^{\circledR}$ MAP, MIHCYTOMAG-60K-05 kit. The $60 \mathrm{kDa}$ PRL stimulus significantly increased TNF- $\alpha$ (220.97 
and $215.40 \mathrm{pg} / \mathrm{ml}$, respectively) and IL-1 $\beta$ (10.08 and $10.39 \mathrm{pg} / \mathrm{ml}$, respectively) (Fig. 4). The production of IL-12, IL-6 and IL-10 was not detected under the conditions set for this assays.

\section{Discussion}

Prolactin (PRL) activates signaling pathways that regulate cell proliferation, migration, differentiation and apoptosis; therefore, it has been implicated in the etiology and progression of cancer $(1,37,43)$.

Even though pituitary gland is the main source of this hormone, there are several cells and tissues that can produce it such as brain, decidua, spleen, adipocytes and breast cancer cells among others. In the same context,PRLR is also expressed, which suggests an autocrine/paracrine mechanism (7).

However, opposite effects have been found on prostate cancer cell lines: rec-hPRL, induces apoptosis in LNCaP cells, but not in PC3 cells (44). This demonstrates that PRL can modulate different actions depending on the type of tumor.

Previous studies of our group demonstrated that rec-hPRL induces apoptosis inhibition in cervical cancer cells (23). Similar effects were observed in ovarian carcinoma, where the rec-hPRL did not affect proliferation, but it decreased apoptosis (45).

The molecular heterogeneity of PRL has been previously described (46), and we have provided evidence that the cell lines and tissues of cervical cancer synthesize a $60 \mathrm{kDa}$ PRL variant, unlike the non-tumorigenic keratinocytes (HaCaT) that do not express this isoform $(23,40)$. This PRL variant has been previously detected in PBMCs from patients with SLE and THP1 monocytes $(25,32)$.

Consequently, we hypothesize that the expression of an autocrine/paracrine loop of PRL may play an important role in the tumoral microenvironment in cervical cancer that can lead to changes in cell proliferation, apoptosis and immune response, among other functions.

PRL is a pleiotropic hormone whose effects can affect cellular processes that may favor the development of cancer. Once the presence of PRL of $60 \mathrm{kDa}$ was identified in the supernatant of the 3 cell lines derived from cervical cancer, we considered it may be important to determine whether the $60 \mathrm{kDa}$ PRL was bioactive and whether it was performing some functions in these cells.

After the isolation of $60 \mathrm{kDa}$ PRL from supernatants of HeLa cells, its bioactivity was tested. In the present study, a high proliferative bioactivity of the PRL of $60 \mathrm{kDa}$ was demonstrated on $\mathrm{Nb} 2$ cells. These results are in concordance with the activity of PRL derived from PBMCs of SLE patients in the same cells (25).

Unlike the study of Larrea $e t a l$, in which stimuli were performed with the complete supernatant from PBMCs (25), in the present study purified $60 \mathrm{kDa}$ PRL from cervical cancer cell supernatants was used to avoid masked effects of other molecules contained in the culture medium.

To prevent any interference due to hormones present in the FBS, charcoal stripped serum was used and; moreover, we corroborated that there was no presence of PRL or the levels are so low they cannot be detected.
Subsequently, we determined that $60 \mathrm{kDa}$ PRL decreases apoptosis in HeLa, SiHa and C-33A cells, and it is able to phosphorylate STAT3 in a similar way to that observed in response rec-hPRL (31).

The high STAT3 expression has been related to many types of cancer such as prostate $(47)$, breast $(48,49)$, skin $(50,51)$ and gliomas $(52,53)$. In a recent study of Shukla et al, a positive correlation between STAT3 and increased E6/E7 expression as well as a diminished $\mathrm{p} 53 / \mathrm{pRB}$ were shown, which opens the possibility to focus on therapeutic targets blocking STAT3. In the latter, curcumin is proposed as a potential candidate (54). In the same regard, there are other molecules proposed as STAT3 blockers such as SC99, proved in an antimyeloma model with ability to induce apoptosis in a selective STAT3 downregulation manner (55); however, on cervical cancer there is only one study involving an in vitro model where IL-37 inhibits STAT3 and supressed proliferation of cervical cancer cells (56).

The latter effects may be carried out by expression of antiapoptotic genes, such as bcl-2, bcl-xl and survivin. In preliminary experiments we observed that in HeLa cells there was an increase of Bcl-xL and survivin in response to etoposide, and these proteins showed a decrease when $60 \mathrm{kDa}$ PRL was added. Whereas in SiHa cells, Bcl-xL and survivin do not show this tendence. These results may be explained since it is well known that antiapoptotic proteins are redundant in their functions (57-59), and this is why it may occur that one or another protein is expressed and in some cases both; however, more experiments must be performed in order to conclude with more certainty.

It may be interesting to use siRNAs to block the translation of $60 \mathrm{kDa}$ PRL, however, it is necessary to characterize first the mRNA sequence to design a specific probe to carry out this assay. Nevertheless, this is a perspective our group is eager to investigate in future studies.

Regarding the immune system in cervical cancer, it is known that in early stages of precancerous cervical lesions there is a proinflammatory cytokine profile in the cervical microenvironment; however, in late phases, or cancer, this profile is shifted to an anti-inflammatory one, characterized by immunosuppressor cytokines $(60,61)$.

One limitation of the present study was not blocking the $60 \mathrm{kDa}$ PRL. However, it is necessary to characterize first the sequence of the protein, in order to use a specific antibody to directly inhibit $60 \mathrm{kDa}$ PRL. This is an ongoing project we are currently working on.

We demonstrate that the $60 \mathrm{kDa}$ PRL has the capacity to induce production of proinflammatory cytokines (IL-1 $\beta$ and TNF- $\alpha$ ) in THP-1 macrophages at the concentration used. However, no IL-6, IL-12 or IL-10 production was detected. Previous studies show that rec-hPRL induces expression of TNF- $\alpha$, IFN- $\gamma$, IL-12 and IL- $1 \beta$ in THP-1 macrophages using the concentration $100 \mathrm{ng} / \mathrm{ml}$, and, as for the case of IL-10, its induction requires a higher concentration $(1,000 \mathrm{ng} / \mathrm{ml})(9,10)$. Further analysis must be performed to evaluate the complete immune role of the $60 \mathrm{kDa}$ PRL on THP-1 macrophages or other cells.

In conclusion, we have shown that cervical cancer cells synthesize and secrete a $60 \mathrm{kDa}$ PRL isoform that can inhibit apoptosis, and it can activate STAT3. In addition, this PRL 
form induces IL-1 $\beta$ and TNF- $\alpha$ production in THP-1 macrophages. It may be interesting to evaluate a broader panel of cytokines to establish PRL autocrine/paracrine effects on the inflammatory response in cervical cancer.

\section{Acknowledgements}

The present study was supported by grant from the Consejo Nacional de Ciencia y Tecnología, Fondo SEP-CONACYT CB-2013-01 (222205). The authors would like to thank Diana Jennifer Carrillo Casillas and José David Ramos Solano for proof reading the manuscript.

\section{Competing interests}

The authors declare that they have no competing interests.

\section{References}

1. Goffin V, Binart N, Touraine P and Kelly PA: Prolactin: The new biology of an old hormone. Annu Rev Physiol 64: 47-67, 2002.

2. Reber PM: Prolactin and immunomodulation. Am J Med 95: 637-644, 1993.

3. Freeman ME, Kanyicska B, Lerant A and Nagy G: Prolactin: Structure, function, and regulation of secretion. Physiol Rev 80 1523-631, 2000

4. Athreya BH, Pletcher J, Zulian F, Weiner DB and Williams WV: Subset-specific effects of sex hormones and pituitary gonadotropins on human lymphocyte proliferation in vitro. Clin Immunol Immunopathol 66: 201-211, 1993.

5. Matera L, Mori M and Galetto A: Galetto, Effect of prolactin on the antigen presenting function of monocyte-derived dendritic cells. Lupus 10: 728-734, 2001.

6. Lahat N, Miller A, Shtiller R and Touby E: Differential effects of prolactin upon activation and differentiation of human $\mathrm{B}$ lymphocytes. J Neuroimmunol 47: 35-40, 1993.

7. Ben-Jonathan N, Mershon JL, Allen DL and Steinmetz RW: Extrapituitary prolactin: Distribution, regulation, functions, and clinical aspects. Endocr Rev 17: 639-669, 1996.

8. De Bellis A, Bizzarro A, Pivonello R, Lombardi G and Bellastella A: Prolactin and autoimmunity. Pituitary 8: 25-30, 2005.

9. Sodhi A and Tripathi A: Prolactin and growth hormone induce differential cytokine and chemokine profile in murine peritoneal macrophages in vitro: Involvement of p-38 MAP kinase, STAT3 and NF-kappaB. Cytokine 41: 162-173, 2008

10. Tripathi, A and Sodhi A: Prolactin-induced production of cytokines in macrophages in vitro involves JAK/STAT and JNK MAPK pathways. Int Immunol 20: 327-336, 2008.

11. Corbacho AM, Macotela Y, Nava G, Eiserich JP, Cross CE, Martínez de la Escalera G and Clapp C: Cytokine induction of prolactin receptors mediates prolactin inhibition of nitric oxide synthesis in pulmonary fibroblasts. FEBS Lett 544: 171-175, 2003.

12. Jara LJ, Vera-Lastra O, Miranda JM, Alcala M and AlvarezNemegyei J: Prolactin in human systemic lupus erythematosus Lupus 10: 748-756, 2001.

13. Chikanza IC, Petrou P, Chrousos G, Kingsley G and Panayi GS: Excessive and dysregulated secretion of prolactin in rheumatoid arthritis: Immunopathogenetic and therapeutic implications. Br J Rheumatol 32: 445-448, 1993.

14. El Miedany YM, Ahmed I, Moustafa H and El Baddini M: Hyperprolactinemia in Sjogren's syndrome: A patient subset or a disease manifestation? Joint Bone Spine 71: 203-208, 2004.

15. Chikanza IC: Prolactin and neuroimmunomodulation: in vitro and in vivo observations. Ann NY Acad Sci 876: 119-130, 1999.

16. Nicoletti F, Di Marco R, Barcellini W, Magro G, Schorlemmer HU, Kurrle R, Lunetta M, Grasso S, Zaccone P and Meroni P: Protection from experimental autoimmune diabetes in the non-obese diabetic mouse with soluble interleukin-1 receptor. Eur J Immunol 24: 1843-1847, 1994.
17. Nicoletti F, Zaccone P, Di Marco R, Lunetta M, Magro G, Grasso S, Meroni P and Garotta G: Prevention of spontaneous autoimmune diabetes in diabetes-prone BB rats by prophylactic treatment with antirat interferon-gamma antibody. Endocrinology 138: 281-288, 1997

18. Joosten LA, Helsen MM, van de Loo FA and van den Berg WB: Anticytokine treatment of established type II collagen-induced arthritis in DBA/1 mice: A comparative study using antiTNFalpha, anti-IL-1alpha/beta and IL-1Ra. Arthritis Rheum 58: S110-S122, 2008

19. Sinha YN: Structural variants of prolactin: Occurrence and physiological significance. Endocr Rev 16: 354-369, 1995.

20. Sinha YN: Prolactin variants. Trends Endocrinol Metab 3: 100-106, 1992.

21. Champier J, Claustrat B, Sassolas G and Berger M: Detection and enzymatic deglycosylation of a glycosylated variant of prolactin in human plasma. FEBS Lett 212: 220-224, 1987.

22. González-Lucano LR, Muñoz-Valle JF, Ascencio-Cedillo R, Domínguez-Rosales JA, López-Rincón G, Del Toro-Arreola S, Bueno-Topete M, Daneri-Navarro A, Estrada-Chávez C and Pereira-Suárez AL: Increased expression of the prolactin receptor is associated with malignant laryngeal tumors. Exp Ther Med 3: 603-607, 2012

23. Lopez-Pulido EI, Muñoz-Valle JF, Del Toro-Arreola S, Jave-Suárez LF, Bueno-Topete MR, Estrada-Chávez C and Pereira-Suárez AL: High expression of prolactin receptor is associated with cell survival in cervical cancer cells. Cancer Cell Int 13: 103, 2013

24. López-Rincón G, Pereira-Suárez AL, Del Toro-Arreola S, Sánchez-Hernández PE, Ochoa-Zarzosa A, Muñoz-Valle JF and Estrada-Chávez C: Lipopolysaccharide induces the expression of an autocrine prolactin loop enhancing inflammatory response in monocytes. J Inflamm 10: 24, 2013.

25. Larrea F, Martínez-Castillo A, Cabrera V, Alcocer-Varela J, Queipo G, Cariño C and Alarcón-Segovia D: A bioactive 60-kilodalton prolactin species is preferentially secreted in cultures of mitogen-stimulated and nonstimulated peripheral blood mononuclear cells from subjects with systemic lupus erythematosus. J Clin Endocrinol Metab 82: 3664-3669, 1997.

26. Goffin V, Binart N, Clément-Lacroix P, Bouchard B, Bole-Feysot C, Edery M, Lucas BK, Touraine P, Pezet A, Maaskant R, et al: From the molecular biology of prolactin and its receptor to the lessons learned from knockout mice models. Genet Anal 15: 189-201, 1999.

27. Schindler C: Cytokines and JAK-STAT signaling. Exp Cell Res 253: 7-14, 1999.

28. Das, R and Vonderhaar BK: Involvement of SHC, GRB2, SOS and RAS in prolactin signal transduction in mammary epithelial cells. Oncogene 13: 1139-1145, 1996.

29. Domínguez-Cáceres MA, García-Martínez JM, Calcabrini A, González L, Porque PG, León J and Martín-Pérez J: Prolactin induces c-Myc expression and cell survival through activation of Src/Akt pathway in lymphoid cells. Oncogene 23: 7378-7390, 2004.

30. Berlanga JJ, Gualillo O, Buteau H, Applanat M, Kelly PA and Edery M: Prolactin activates tyrosyl phosphorylation of insulin receptor substrate 1 and phosphatidylinositol-3-OH kinase. J Biol Chem 272: 2050-2052, 1997.

31. Ramírez de Arellano A, Lopez-Pulido EI, Martínez-Neri PA, Estrada Chávez C, González Lucano R, Fafutis-Morris M, Aguilar-Lemarroy A, Muñoz-Valle JF and Pereira-Suárez AL: STAT3 activation is required for the antiapoptotic effects of prolactin in cervical cancer cells. Cancer Cell Int 15: 83, 2015.

32. López-Rincón G, Mancilla R, Pereira-Suárez AL, Martínez-Neri PA, Ochoa-Zarzosa A, Muñoz-Valle JF and Estrada-Chávez C: Expression of autocrine prolactin and the short isoform of prolactin receptor are associated with inflammatory response and apoptosis in monocytes stimulated with Mycobacterium bovis proteins. Exp Mol Pathol 98: 517-526, 2015.

33. Yonezawa T, Chen KH, Ghosh MK, Rivera L, Dill R, Ma L, Villa PA, Kawaminami $M$ and Walker AM: Anti-metastatic outcome of isoform-specific prolactin receptor targeting in breast cancer. Cancer Lett 366: 84-92, 2015.

34. Neradugomma NK, Subramaniam D, Tawfsik OW, Goffin V, Kumar TR, Jensen RA and Anant S: Prolactin signaling enhances colon cancer stemness by modulating Notch signaling in a Jak2-STAT3/ERK manner. Carcinogenesis 35: 795-806, 2014. 
35. Goffin V, Hoang DT, Bogorad RL and Nevalainen MT: Prolactin regulation of the prostate gland: A female player in a male game. Nat Rev Urol 8: 597-607, 2011.

36. Robertson FG, Harris J, Naylor MJ, Oakes SR, Kindblom J, Dillner K, Wennbo H, Törnell J, Kelly PA, Green J and Ormandy CJ: Prostate development and carcinogenesis in prolactin receptor knockout mice. Endocrinology 144: 3196-3205, 2003.

37. Clevenger CV, Furth PA, Hankinson SE and Schuler LA: The role of prolactin in mammary carcinoma. Endocr Rev 24: 1-27, 2003.

38. Tworoger SS and Hankinson SE: Prolactin and breast cancer etiology: An epidemiologic perspective. J Mammary Gland Biol Neoplasia 13: 41-53, 2008.

39. Jemal A, Bray F, Center MM, Ferlay J, Ward E and Forman D: Global cancer statistics. CA Cancer J Clin 61: 69-90, 2011.

40. Ascencio-Cedillo R, López-Pulido EI, Muñoz-Valle JF, Villegas-Sepúlveda N, Del Toro-Arreola S, Estrada-Chávez C, Daneri-Navarro A, Franco-Topete R, Pérez-Montiel D, GarcíaCarrancá A and Pereira-Suárez AL: Prolactin and prolactin receptor expression in cervical intraepithelial neoplasia and cancer. Pathol Oncol Res 21: 241-246, 2014.

41. Gout PW, Beer CT and Noble RL: Prolactin-stimulated growth of cell cultures established from malignant $\mathrm{Nb}$ rat lymphomas. Cancer Res 40: 2433-2436, 1980.

42. Noble RL, Beer CT and Gout PW: Evidence in vivo and in vitro of a role for the pituitary in the growth of malignant lymphomas in $\mathrm{Nb}$ rats. Cancer Res 40: 2437-2440, 1980.

43. Perks CM, Keith AJ, Goodhew KL, Savage PB, Winters ZE and Holly JM: Prolactin acts as a potent survival factor for human breast cancer cell lines. Br J Cancer 91: 305-311, 2004.

44. Giuffrida D, Perdichizzi A, Giuffrida MC, La Vignera S, D'Agata R, Vicari E and Calogero AE: Does prolactin induce apoptosis? Evidences in a prostate cancer in vitro model. J Endocrinol Invest 33: 313-317, 2010.

45. Asai-Sato M, Nagashima Y, Miyagi E, Sato K, Ohta I, Vonderhaar BK and Hirahara F: Prolactin inhibits apoptosis of ovarian carcinoma cells induced by serum starvation or cisplatin treatment. Int J Cancer 115: 539-544, 2005.

46. Shoupe D, Montz FJ, Kletzky OA and diZerega GS: Prolactin molecular heterogeneity. Response to thyrotropin-releasing hormone stimulation of concanavalin A-bound and -unbound immunoassayable prolactin during human pregnancy. Am J Obstet Gynecol 147: 482-487, 1983.

47. Qin HR, Kim HJ, Kim JY, Hurt EM, Klarmann GJ, Kawasaki BT, Duhagon Serrat MA and Farrar WL: Activation of signal transducer and activator of transcription 3 through a phosphomimetic serine 727 promotes prostate tumorigenesis independent of tyrosine 705 phosphorylation. Cancer Res 68: 7736-7741, 2008.
48. Clevenger CV: Roles and regulation of stat family transcription factors in human breast cancer. Am J Pathol 165: 1449-1460, 2004.

49. Ling $X$ and Arlinghaus RB: Knockdown of STAT3 expression by RNA interference inhibits the induction of breast tumors in immunocompetent mice. Cancer Res 65: 2532-2536, 2005.

50. Chan KS, Sano S, Kiguchi K, Anders J, Komazawa N, Takeda J and DiGiovanni J: Disruption of Stat3 reveals a critical role in both the initiation and the promotion stages of epithelial carcinogenesis. J Clin Invest 114: 720-728, 2004.

51. Pedranzini L, Leitch A and Bromberg J: Stat3 is required for the development of skin cancer. J Clin Invest 114: 619-622, 2004.

52. Alvarez JV, Mukherjee N, Chakravarti A, Robe P, Zhai G, Chakladar A, Loeffler J, Black P and Frank DA: A STAT3 gene expression signature in gliomas is associated with a poor prognosis. Transl Oncogenomics 2: 99-105, 2007.

53. Abou-Ghazal M, Yang DS, Qiao W, Reina-Ortiz C, Wei J, Kong LY, Fuller GN, Hiraoka N, Priebe W, Sawaya R and Heimberger AB: The incidence, correlation with tumor-infiltrating inflammation, and prognosis of phosphorylated STAT3 expression in human gliomas. Clin Cancer Res 14: 8228-8235, 2008.

54. Shukla S, Mahata S, Shishodia G, Pandey A, Tyagi A, Vishnoi K, Basir SF, Das BC and Bharti AC: Functional regulatory role of STAT3 in HPV16-mediated cervical carcinogenesis. PLoS One 8: e67849, 2013.

55. Zhang Z, Mao H, Du X, Zhu J, Xu Y, Wang S, Xu X, Ji P, Yu Y, Cao B, et al: A novel small molecule agent displays potent anti-myeloma activity by inhibiting the JAK2-STAT3 signaling pathway. Oncotarget 7: 9296-9308, 2016.

56. Wang S, An W, Yao Y, Chen R, Zheng X, Yang W, Zhao Y, Hu X, Jiang E, Bie Y, et al: Interleukin 37 expression inhibits STAT3 to suppress the proliferation and invasion of human cervical cancer cells. J Cancer 6: 962-969, 2015.

57. Eichhorn JM, Alford SE, Sakurikar N and Chambers TC: Molecular analysis of functional redundancy among antiapoptotic Bcl-2 proteins and its role in cancer cell survival. Exp Cell Res 322: 415-424, 2014.

58. Chao DT, Linette GP, Boise LH, White LS, Thompson CB and Korsmeyer SJ: Bcl-XL and Bcl-2 repress a common pathway of cell death. J Exp Med 182: 821-828, 1995.

59. Villunger A, Scott C, Bouillet $P$ and Strasser A: Essential role for the $\mathrm{BH} 3$-only protein Bim but redundant roles for Bax, Bcl-2, and Bcl-w in the control of granulocyte survival. Blood 101: 2393-2400, 2003.

60. Paradkar PH, Joshi JV, Mertia PN, Agashe SV and Vaidya RA: Role of cytokines in genesis, progression and prognosis of cervical cancer. Asian Pac J Cancer Prev 15: 3851-3864, 2014.

61. Goncalves MA and Donadi EA: Immune cellular response to HPV: Current concepts. Braz J Infect Dis 8: 1-9, 2004. 